\title{
INTERVENING IMPOSSIBILITY OF PERFORMANCE AS AFFECTING THE OBLIGATIONS OF CONTRACTS.
}

"Business contracts must be construed with business sense, as they naturally would be understood by intelligent men of affairs."

It would be well to have the foregoing quotation from the opinion of the Supreme Court, handed down May 7, 1917, in the case of the "Kronprinzessin Cecilie," blazoned in a high place in many court rooms, and it would have a salutary effect if the Supreme Court frequently used language of this sort to bring home to the Judiciary of the country the need for breaking away from the fetters of stare decisis, with a view to accommodating judicial decrees to the needs of an expanding and changing community, needs to which business men are adapting themselves daily.

The courts of England were quick to make reasonable and common-sense application of old rules to the multiplicity of questions arising out of the novel situations presented by changing business conditions during the present war.

Many hard and fast rules of the common law affecting contracts have been modified and their rigor relaxed in favor of making the rule of liability of contracting parties more nearly approach equitable considerations and the obligations imposed more nearly commensurate with the situation and surroundings and capability of performance of contracting parties.

The rights of parties to contracts, affected by governmental interference, as by requisition or commandeering, have been equitably adjusted, so that the benefits of compensation by the Government or the losses incident to the activity of the Government may be equitably divided between the parties to the. contract. ${ }^{1}$

During the present war in which this country is now engaged, because of the many changes in contracts, which the activities of the Government and the exigencies of the abnormal

'See decision of Judge Rowlatt in the case of Chinese Engineering \& Mining Co., Itd., v. Sale \& Co., II K. B. (1917) 599. See also Modern Trans. Co. v. Dunerie S. S. Co., I K. B. Div. (I9I7) 370.

(28) 
situations will bring about, no rule of law will perhaps be more applied and call more frequently for judicial interpretation than the so-called rule in Paradine v. Jane. ${ }^{2}$

The exact question presented for decision in Paradine v. Jane, was whether a lessee who had covenanted to pay rent was required to do so, although ousted from possession by a superior enemy force. The defendant pleaded

"that a certain German prince, by name Prince Rupert, an alien born, enemy to the King and his kingdom, had invaded the realm with a hostile army of men; and with the same force did enter upon the defendant's possession, had him expelled, and held out of possession . . . whereby he could not take the profits."

This was held to be no excuse for the non-payment of the rent. And the report continues:

"And this difference was taken, that where the law creates a duty or charge, and the party is disabled to perform it without any default in him, and hath no remedy over, there the law will excuse him. As in the case of Waste, if a house be destroyed by tempest, or by enemies, the lessee is excused. . . . But when the party by his own contract creates a duty or charge upon himself, he is bound to make it good, if he may, notwithstanding any accident by inevitable necessity, because he might have provided against it by his contract. And therefore, if the lessee covenant to repair a house, though it may be burnt by lightning or thrown down by enemies, yet he ought to repair it."

It is to be noted that the court in this case required the party to perform that portion of his contract which called for the payment of money because "he might"- that is to say, nothing done by the German prince had prevented his paying money, and, therefore, the defence raised was not a defence which indicated performance prevented by intervening circumstances.

However, following this decision, courts were not wanting which held that if a contract was made to perform an act at a future time, and no exception stated, persons so contracting would be liable for non-performance even though an intervening vent-even an act of God-prevented performance, and rested their decision on their conception of the rule in Paradine v. Jane. As early as 1833 , a writer in the American Jurist ${ }^{3}$ pointed

2 (1647) Aleyn 26.

Io American Jurist 250. 
out the absurdity of this doctrine, and urged a reconsideration of the cases by which the doctrine had been fostered, on the ground that the courts in enforcing contracts where performance was rendered impossible, were really adding a term to the contract made by the parties - the courts were making the contract read that performance would take place "at all events."

But until the advent of the present war, the rule in England could not be said to have been clearly settled, and much confusion existed in the various decisions of our state and federal courts.

In England, courts, in laying down the rule based upon a strict interpretation of the doctrine in Paradine v. Jane, reached many absurd results. For instance, in Gillespie \& Co.v. Howden Co., ${ }^{4}$ there was a contract for building of a ship of specified dimensions and carrying power, according to a model. When the ship was built it was found to be deficient in the required carrying capacity and in an action for damages by the purchaser, although it was shown to be impossible to build a seaworthy ship of the required dimensions and carrying capacity, according to the model, the court held that this was no excuse.

And in Hills v: Sughrue, where the owner of a ship agreed to load a cargo of guano at Ichaboe, and failed to load, because no guano could be had at Ichaboe, the owner was held liable because of his covenant to load such a cargo.

In Spence v. Chadwick, ${ }^{6}$ a ship owner was held liable on a charter for failure to carry goods which he was unable to carry, because the goods had been seized at Cadiz and condemned as contraband.

So in Jacobs, Marcus \& Co. v. The Credit Lyonais," a defendant was held liable for failure to deliver esparto although failure to deliver was because of the prohibition on the export of esparto from Algeria by the authorities.

- (1885) 12 Sess. Cas. $800^{\circ}$

i5 M. \& W. 252 (1846).

- I6 L. J. R. 313 (I847).

I2 L. R. Q. B. D. 589 (1884). 
In America the rule was applied with the same absurd results in a number of cases. ${ }^{8}$

A good illustration is the case of West v. The Uncle Sam, ${ }^{9}$ where a carrier was held responsible for non-performance of a contract of carriage although he set up impossibility due to the possession of part of his route by a foreign army.

The American rule, formerly applied in all its rigor notwithstanding that the court calls attention to the harshness attendant upon its application, is best stated in the language of the court in Central Trust Co. v. Wabash, St. Louis \& Pacific R. R. Co. ${ }^{10}$ as follows:

"The general rule is that, where an obligation or a duty is imposed upon a person by law, he will be absolved from liability for non-performance of the obligation, if such non-performance was occasioned by an act of God. This rule is illustrated in the case of common carriers. The rule, however, is just as clear that, when a man undertakes by an express contract to do a given act, he is not absolved from liability for non-performance, even though he is prevented from doing the same by an act of God. In that class of cases, if a person desires to absolve himself from liability for non-performance under any circumstances, he should so stipulate in his contract."

Beginning with the case of Taylor $\mathcal{E}$ Caldwell, ${ }^{11}$ in England, and Chicago, Milwaukee \& St. Paul. Ry. v. Hoyt, ${ }^{12}$ in America, there was manifest a tendency to construe with more liberality, contracts for performance in futuro and not to read into covenants to perform a certain thing, the words "at all events."

A survey of the various cases where the defense of impossibility, intervening subsequent to the making of the contract, was considered, indicates that both in England and America the following rules obtain:

I. It is a good defense to an absolute agreement to perform an act, that performance has been rendered illegal

- See Jones v. U. S., 96 U. S. 24 (I887) ; Texas \& St. Louis Ry. Co. v. Rust, I9 Federal 239 (I883).

- (1859) Fed. Cas. 17427.

${ }^{10} 31$ Fed. 440 (1887).

${ }_{3}$ B. \& S. 826 (1863).

"I 49 U. S. I (1892). 
by reason of a change in the law; although as we shall see, this rule is not as yet clearly defined owing to the confusion on the subject caused by the decision in the case of the Tweedie Trading Co. v. James $P$. $M c$ Donald $\mathrm{Co}^{13}$ which holds that a change in foreign law which makes performance illegal or even impossible, is not a defense.

2. It is a good defense that the specific thing, the existence of which is essential to performance of the contract, is destroyed.

3. It is a good defense in the case of a contract for personal services, that the party to perform, is incapacitated by sickness.

A fourth excuse for non-performance and one of broader and equally logical application, results from the language of the Supreme Court in the "Kronprinzessin" case when speaking of the contract in that case-the bill of lading - the court said :

"It embodied simply an ordinary bailment of a common carrier subject to the implied exceptions which it would be extravagant to say would be excluded because they were not written in."

This doctrine is not altogether new, but it has never been expressed in this form by the courts before. It was referred to by the New York courts in the case of Kinser Construction Co. v. State ${ }^{14}$ as a situation "where conditions essential to performance do not exist."

Mr. Frederick C. Woodward, writing in the Columbia Law Review, ${ }^{15}$ suggested this fourth exception as follows:

"If the contingency which makes the contract impossible of performance is such that the parties to the contract, had they actually contemplated it, would probably have regarded it as so obviously terminating the obligation as not to require expression, failure of performance should be excused."

Such a statement of the rule is, however, entirely too narrow, and, indeed, was not, at the time it was suggested, in

\footnotetext{
* II4 Fed. 985 (1902).

${ }^{16}$ I25 N. Y. S. 46 (1910).

1s Vol. I, p. 533 .
} 
accordance with the language of the Supreme Court in the case of Chicago, Milwankee \& St. Paul Ry. v. Hoyt, ${ }^{16}$ as follows:

"There can be no question that a party may by an absolute contract bind himself or itself to perform things which subsequently become impossible or pay damages for the non-performance, and such construction is to be put upon an unqualified undertaking, where the event which causes the impossibility might have been anticipated and guarded against in the contract or where the impossibility arises from the act or default of the promisor. But where the event is of such a character that it cannot be reasonably supposed to have been in the contemplation of the contracting parties when the contract was made, they will not be held bound by general words, which though large enough to include were not used with reference to the possibility of the particular contingency which afterwards happens."

The extent of the present-day doctrine in England that an intervening contingency which makes for impossibility of performance of the contract, is a defence, is clearly set forth in the case of Horlock v. Beale ${ }^{17}$ where all of the authorities were reviewed by Earl Loreburn and the limitations on the doctrine were clearly laid down by the same judge in the subsequent case of Tamplin v. Anglo-Mexican Co. ${ }^{18}$

In the case of Horlock v. Beale, the wife of a seaman who had agreed to serve on a voyage not exceeding two years' duration, sued on an allotment note given by the shipowner under which he agreed to pay the wife one-half of the monthly wages of her husband during the period of the voyage. The ship on which the husband was serving as a seaman was in the port of Hamburg at the outbreak of the war between England and Germany and the ship and seamen were detained in that port, the seamen being subsequently interned in Germany near Berlin.

The wife sued on the contract for the wages and the defendant set up impossibility of performance of the contract because of the intervention of the German government.

The case itself was first tried before a judge of the Commercial Court who found that the defense of impossibility of performance could not absolve the shipowner. An appeal from

4 149 U. S. I (I892).

${ }^{17}$ L. R. I App. Cas. (Ig16) 486.

${ }^{13}$ L. R. 2 App. Cas. (1916) 397. 
this judgment was taken to the Court of Appeals and that court affirmed the judgment of the lower court.

On appeal to the House of Lords that body considered the question as one involving solely the question of impossibility of performance intervening after the making of a contract.

Lord Loreburn speaking for the majority stated:

"In my view the first question to be decided is whether or not and at what date the performance of this contract of service became impossible, which means impracticable in a commercial sense,"

and after finding that the date of internment was the date which made the contract impossible of performance stated the ruling to be as follows:

"In my opinion, neither party was any longer bound by that contract from that date. If they were bound it must mean that wages were to be paid, without any service in return, for the entire duration of this war, or, in the present case, till the expiry of two years from the commencement of the service. The Napoleonic war after the rupture of the Peace of Amiens lasted for eleven years. I think it was an implied term of this service, subject to any special law affecting seamen, that it should be practicable for the ship to sail on this voyage, in that sense which disregards minor interruptions and takes notice only of what substantially ends the possibility of the service contemplated being fulfilled. Both employer and employed made their bargain on the footing that, whatever temporary interruption might supervene, the ship and crew would be available to carry out the adventure."

It was in this language that the court enunciated the doctrine that a subsequent event which completely frustrates the basic purpose of the contract, or destroys the object for which it is made, will discharge the obligations of the contracting parties, because the court will imply into a contract an exception to govern the subsequent happening. To hold otherwise would be really to add to the contract between the parties, the term that performance will be made "at all events."

Lord Shaw of Dunfermline, relied in his concurring judgment very much upon the authority of Mr. Justice Blackburn, who had laid down the ruling in Taylor v. Caldwell, ${ }^{19}$ that in

${ }^{10} 3$ B. \& S. 826 (1863). 
"a positive contract to do a thing, not in itself unlawful, the contractor must perform or pay damages for not performing, although in consequence of unforeseen accidents, the performance of his contract had become impossible,".

but held the rule applicable only to a contract positive and absolute and not subject to any condition express or implied, holding that where from the nature of the contract it would appear that the parties from the beginning must have known that it could not be performed unless at the time for performance some specific thing continued to exist, then they must at the making of the contract have contemplated the continued existence as its foundation and the contract would be construed, although a positive contract, as subject to an implied condition that the parties will be excused in case before breach, performance becomes impossible from the perishing of the thing without the fault of either party.

Lord Blackburn's opinion, in Taylor v. Caldwell, supra, was founded upon his survey of the Civil Law. He cited Digest 45, I, 33 and Digest $46, I, 23$, to the effect that the obligation of a contract is founded upon the certo corpore and cites the illustration given in the Digest of a promise with regard to a slave, viz., that if under a contract to transfer a slave, before performance was due, the slave died or was manumitted, the contracting party was freed of his obligation, unless, of course, he was responsible for either the death or manumission, and, unless, of course, he had by some definite stipulation, taken on himself the risk of the happening of the event.

Lord Shaw of Dunfermline points out that the research of Mr. Justice Blackburn in the Civil Law, had not been exhaustive and that the doctrine set forth in Taylor v. Caldwell was more extensive even in the Civil Law, citing Digest 45, I, 9 I and Book I8, de contrahenda emptione.

Lord Shaw observes that not only had the principle been laid down in the Civil Law, but its modern development as enunciated in Horlock v. Beale, supra, had been foreshadowed in Roman times, quoting from Mr. Hunter on Roman Law, page 638 , the following dictum: 
"Sempronius promises to give a small plot of ground to Maevius. After doing so, he buries a dead body in the place, and thus makes the land extra-commercium. Sempronius must pay its value. If the land had belonged to another, who had buried a body in it, he would have been released."

He points out that this illustration shows that if the basis of the transaction-the root of the contract-the thing which was in contemplation of the parties, has ceased to exist, or has suffered such an alteration as to prevent performance, the obligation itself falls, and states the rule as follows:

"The underlying ratio is the failure of something which was at the basis of the contract in the mind and intention of the contracting parties.

"The ratio has, I am humbly of opinion, been properly developed in recent years. I do not go through all the decisions,. but I think it right to mention that of Krell [Krell v. Henry, $2 \mathrm{~K}$. $\overline{\mathrm{B}}$. 740 (1903)], in which I desire to attach my respectful and pointed concurrence in the opinion delivered by Vaughan Williams, L. J., in these passages: "Whatever may have been the limits of the Roman law, the case of Nickoll v. Ashton makes it plain that the English law applies the principle not only to cases where the performance of the contract becomes impossible by the cessation of existence of the thing which is the subject-matter of the contract, but also to cases where the event which renders the contract incapable of performance is the cessation or non-existence of an express condition or state of things going to the root of the contract.'

"This view is fully discussed by the learned judge. I think it to be in entire accord with that doctrine of frustration of voyage which has become fully accepted since the case of Jackson v. Union Marine Ins. Co. with the doctrine underlying Taylor v. Caldwell, and with sound legal principle."

It will be of advantage perhaps for the sake of clearness to set out the rule in the language of Lord Wrenbury, who filed a concurring opinion in Horlock v. Beale:

"Where a contract has been entered into, and by a supervening cause beyond the control of either party its performance has become impossible, I take the law to be as follows: If a party has expressly contracted to do a lawful act, come what will-if, in other words, he has taken upon himself the risk of such a supervening cause-he is liable if it occurs, because by the very hypothesis he has contracted to be liable. But if he had not expressly so contracted, and from the nature of the contract it appears that the parties from the first must have known that its fulfilment would become impossible if such a supervening cause occurred, then upon such a cause occurring both parties are excused from performance. In that case a 
condition is implied that if performance becomes impossible the contract shall not remain binding. The leading case on the subject is Taylor v. Caldwell. Krell v. Henry is an illustration of the application of the principle."

In England therefore it appears that the doctrine that an intervening contingency which renders performance impossible will be an excuse, even though a positive contract has been made to do a thing, is not firmly fixed.

In America we think that the rule is broadened and any doubt set at rest by the language of the Supreme Court in the case of the "Kronprinzessin Cecilie."

In that case the Supreme Court had to decide between the conflicting claims presented on the one side by the claim of the libellants of the "Kronprinzessin Cecilie" that having shipped their gold under a bill of lading which was an absolute agreement to transport, subject only to the exception of arrest and restraint of princes, rulers and peoples, and containing no other exception, and, therefore (exceptions noted excluded), creating an obligation on the part of the steamship to transport the gold at all events, and the claim, on the other hand, of the respondents, that regardless of any exception contained in the bill of lading, the court should imply in the contract of the parties an exception covering the situation arising out of the war, because to hold that the parties would have contracted as they did, with such a situation in contemplation would be extravagant.

It is interesting to observe that although the case of Paradine v. Jane was adverted to in the argument before the court, the decisions of the House of Lords in the case of Horlock v. Beal, and in the case of Tamplin Steamship Co. v. Anglo-Mexican Petroleum Products $\mathrm{Co}^{20}$ seem not to have been called to the attention of the court, but whether or not those cases were before the court the result reached by our Supreme Court was identical with the results reached by the House of Lords in both cases mentioned, and these results should settle for all time the question of intervening impossibility of performance as affecting obligations of a party to a contract.

$$
20 \text { I. R. App. Cas. (1916) } 397 .
$$


It remains to consider the effect of the decision of the Supreme Court in the "Kronprinzessin Cecilie" case upon the decision of the District Court of New York in the case of the Tweedie Trading Co. v. James P. McDonald Co. ${ }^{21}$ In the latter case the action was in admiralty. The libellant and defendant had entered into a contract in the United States by which the libellant agreed to make four trips with its steamship from Barbadoes to Colon to transport laborers for the defendant. The defendant contracted to pay a stated sum for each trip. The contract when made was legal and valid in the United States and also at Barbadoes. After two trips had been made a regulation of the colonial government of the Barbadoes was put into effect' which forbade the future embarkation of laborers. The defendant, therefore, was not able to furnish any more laborers for transportation. Suit was brought by the shipowner for the charter hire for the last trip and a cross action was brought by the contractor for repayment of the third installment of charter hire paid by him. The court held the charterer or contractor liable to pay the charter hire for the full four trips and that he was not excused therefrom by reason of the prohibition of the exportation of laborers from the Barbadoes. The court said :22

"The contract was valid in its inception, both at the place of making and the place of performance, and was capable of being performed until an event intervened which was not in the contemplation of the parties when the contract was made. . . . The question really is, do the legal acts of the agents of a foreign government, which prevent the full performance of a contract of this character, control the rights of the parties? Contracting parties are subject to the contingencies of changes in their own law and liable to have the execution of their contracts prevented thereby; but it is on the ground of illegality, not of impossibility. Prevention by the law of a foreign country is not usually deemed an excuse, when the act which was contemplated by the contract was valid in view of the law of the place where it was made. . . ."

While the decision in the case can be supported upon the reasoning running through all of the cases which hold that where

${ }^{21}$ II4 Fed. 985 (I902).

P. 988. 
there is a contract to pay money and the intervening frustrating cause does not prevent the payment of the money, this payment will be required, yet the basis of the decision was not upon this ground, but upon the absurd ground that the foreign law was a "fact" and, apparently, therefore, necessarily must have been in contemplation of the parties, but, in the language of the Supreme Court, it would seem to be "extravagant to say" that because a contract was made in this country, but to be performed in another, that a change of law in the other country making performance impossible, was not such an intervening frustrating circumstance as to warrant the deduction that if the possibility of the change had been drawn to the attention of the contracting parties, that they would not have said "of course, if that occurs, no obligation can be enforced on this contract on either side."

The result of the decisions in both America and England is that unless a contrary intention clearly appears from the contract of the parties, the court will imply an exception to the contract to govern an intervening subsequent event, which makes performance of the contract impossible in fact, and excuse the contracting parties from liability for non-performance, and this is in accord with the dictates of sound business and sound sense.

William J. Conlen.

Philadelphia. 